\title{
New Curriculum: The Concept of Freedom Learning In Music Learning in Department of Music Education
}

\author{
Dani Nur Saputra \\ Department of Music Education, Universitas Negeri Jakarta, Indonesia \\ daninursaputra6@gmail.com
}

\begin{abstract}
Currently, the learning system has demanded in 21st-century skills competencies. Freedom learning concept-independent campus learning is presented to improve the education system in Indonesia. This research aimed to support the new curriculum of policies by applying music learning methods based on the freedom of learning-an independent campus policy for the students. Music education students are educated and trained to be ready to face all challenges in the era of the digital industry 4.0 and society 5.0 today. This type of research is a descriptive qualitative approach to the study of literature relating to the new curriculum of the concept of freedom learning-an independent campus. The results of this study stated that the concept of a freedom learning- an independent campus in music learning was carried out with internships, fieldwork practices, teaching practices, student exchanges, research, entrepreneurship activities, humanitarian programs, as well as across study programs and universities. The new policy requires 21 st-century skills competency so that music education graduates can be employed and able to compete in today's global industry.
\end{abstract}

Keywords: New Curriculum, Freedom learning, Campus Policy, Music Learning

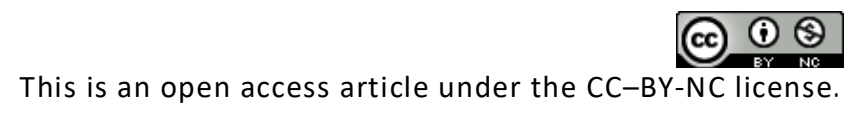

\section{INTRODUCTION}

Recently a new policy has become the topic of hot conversation in Indonesia's education to make a change of the new curriculum. The policy contains the concepts of freedom learning and independent campus. The policy of the Freedom Learning- the Independent Campus aims to improve the graduate's competencies, both soft skills and hard skills (Sudaryanto, et al, 2020). This policy makes universities more ready in challenges of the world demands and to prepare students graduates to face in the global industry.

The policy of the Freedom Learning- the Independent Campus is relatively new in Indonesia and began to be implemented by several schools and universities in 2020. The background of this policy is based on the fact that the relevance of learning materials that have been studied by students in class with the needs of the industrial and field world is still relatively low (Alif et al., 2020). Besides, this new policy is also considered capable of equipping students with new experiences and opening wider horizons of their knowledge and experience (Priatmoko \& Dzakiyyah, 2020).

This study is in line with some of the results of previous studies so that the researcher adds that the policy of the freedom learning refers to 21 st-century learning based on the students centered scientific learning. Students are no longer regulated by the instructors or campus policies and bureaucracy that limit students to explore knowledge that they can acquire more by themselves with 
the technology capabilities possessed by students who are mostly millennials and $\mathrm{Z}$ generations. As a lecture in this era must also be able to deal with the diversity of students from various aspects (Mumpuniarti et al., 2020) and must able to manage diverse student learning needs.

The idea of a new curriculum of the freedom learning raises optimism among universities to be able to develop rapidly and innovate autonomously for the development of all aspects of higher education (Arifin, Syamsul \& Muslim, Moh, 2020). The policy of the concept of freedom learningan independent campus is a challenge for study programs, especially the music education program of Jakarta State University which has to do with its application in music learning. Some things that need to be prepared are the curriculum, learning facilities, course packages, technology, equality, cooperation, independence, and 21st-century skills. The preparation is an important aspect of supporting the policies in efforts to improve the education system in Indonesia. Lack of literacy research on the study of the concept of freedom learning in music learning has an impact on the lack of optimal result in implementing the freedom learning-an independent campus policy. Therefore, this research can also be used as an inspiration and guidance to assist in carrying out the policy of implementing the concept of a freedom learning-an independent campus in the learning system, especially in music learning.

\section{LITERATURE REVIEW}

The concept of independent learning has a philosophical meaning in modern education. Modern education is built based on the desire to change the education system to be better, more effective, and efficient. Modern education can be said to be part of the progressivism flow in the philosophy of education (Mustaghfiroh, 2020) The concept of independent learning underlies an aspect of creativity. Learning is no longer a matter of listening and imitating but of doing and creating. The concept emphasizes the importance of the basics of independence and freedom to students. Students are given the freedom to develop their hidden talents and abilities without being hampered by formal rules which sometimes shackle their creativity and thinking power.

Freedom Education Learning is a response to the needs of the education system in the Industrial Revolution 4.0 era. In the era of the Industrial Revolution 4.0, the main need to be achieved in the education system or more specifically in learning methods is students or learners, namely mastery of new literacy in technology (Yamin \& Syarir, 2020. New curriculum reforms have to take place concurrently with other changes for them to have a significant and long-lasting effect (Bantwini, 2010. The learning process through the concept of freedom learning emphasizes the concept of deeper learning in a more tangible community environment (Elihami, 2019) so that students can experience the knowledge. This approach can not only develop students who are knowledgeable but also can create new mindsets that can respond to life's challenges, increase creativity and innovation in various aspects of life (Tan et al., 2018). A good learning process is not only done through the classroom demonstration but also learns something by doing (learning by doing) so that students can experience the learning process directly (Saputra, 2020). The learning process carried out in the music education program of Jakarta State University involves motor skills in playing music skills. So it is necessary to apply learning methods that are in line with the concept of freedom of learning.

\section{RESEARCH METHODOLOGY}

The type of this research is a descriptive qualitative approach to the study of literature relating to the concept of freedom learning- an independent campus. The core discussion in this study is the application of policies in learning the music of the music education program of Jakarta State University. The data collection is done by a literature study, observation, and interviews. The 
literature study is carried out by collecting data in the form of articles, books, and other documents that are related to the study of literature in this research. Observations were done by observing the conditions of the music education program. observations were made by the researcher recording all the needs needed in implementing the new policy. observations focus on facilities and rooms owned by music education study programs. Based On the notes made, the researcher found several facilities that were incomplete so that new curriculum policies could not be fully implemented. Music education programs only have a few technological devices to support learning. So, at least students are required to have their laptops. Also, the music education study program does not yet have a multimedia room to enable technology-based learning. While interviews were conducted with the head of the study program in dealing with policies that have to do with their application in music learning at the college level. Interviews focused on the readiness of the study program to implement new policies. Based on the interviews conducted, it was found that the music education program was not fully ready to implement the new policy in an independent learning-independent campus. There are still many things that need to be prepared by the study program to run the new curriculum. The collected data is then identified and analyzed descriptively qualitatively by referring to the analysis of Matthew B. Miles and A. Michael Huberman (2009) through data reduction, data presentation, and concluding.

\section{FINDING AND DISCUSSION}

\section{New Curriculum of the Freedom Learning- An Independent Campus Policy}

The new curriculum of the freedom learning- an independent campus policy was launched and first presented to the media by Indonesia's Minister of Education and Culture, Mr. Nadiem Anwar Makarim on Friday, January 24, 2020, in Building D of the Ministry of Education and Culture Office in the Higher Education Policy Coordination Meeting. Since it was first presented in front of the media until now, this policy is still a concern for academics within the universities. The ideas in the concept of the policy raised a warm conversation both from the pro and contra parties of the policy.

There are some contra parties because of the university's readiness to follow and run the policy. The lack of university facilities and relations with other parties is the main trigger in the rejection of the policy in the new curriculum. Whereas the pro parties of the policies are generally mature universities that have readiness from facilities and relationships with other parties outside of campus.

Based on the phenomena that occur in the education system in Indonesia, Minister Nadiem made four ideas in the policies. Here are the ideas in the policy of the concept of the freedom learningan independent campus.

Table 1. The policy of the Freedom Learning-an Independent Campus

\begin{tabular}{ll}
\hline No & Policies \\
\hline 1 & Opening of a New Study Programs \\
2 & The University Accreditation System \\
3 & Legal Entity State University \\
4 & Three Semester Learning Rights outside the Main Study Program
\end{tabular}

The idea related to the policy of the freedom learning - an independent campus presents four main policies in terms of the regulatory system that provides convenience, effectiveness, and efficiency compared to the system that was previously applied. The four main policies are the policy 
of opening new study programs, even A and B accredited universities will be permitted to open new study programs with the requirement of having relationships with several industries and international non-profit organizations, having networks with State-owned enterprises of Indonesia (BUMN) and Local Government Owned Enterprise (BUMD), and has connections with some of the best campuses at the QS World University TOP 100 level. The second point is to facilitate the higher education accreditation system within 5 years automatically, except for the campus that will raise its level of accreditation. The third point is giving opportunities for Perguruan Tinggi Negeri Badan Layanan Umum dan Satuan Kerja to become state universities with legal status. The fourth point is the granting of study rights for students to study outside of their study program. In this case, the campus has the right to offer this right, but students are also given the right to make their own choices. If a student wishes to continue studying in his program, the campus has no right to prohibit it. However, if students want to take courses outside of their study programs, the campus has the right to facilitate and fully support the study rights for students.

\section{$21^{\text {st }}$ Century Competence That Students Should Have}

The Music Education Program of Jakarta State University is a place for students to deepen their knowledge in music, while music education is a field of study in the application of teaching and learning of music. This knowledge covers aspects of psychomotor, cognitive, and effective. The focus of learning in the Music Education Program refers to the pedagogic field where graduates will be directed to become instructors and educators of art. About the graduate profile, the Music Education Program prepares a series of knowledge for students to be ready to compete in the global industry. Students are not only required to learn but apply what is learned.

Music learning in the current era should be related to a real-life situation. Students decide to study in a particular field of study because they consider the world of work that they will live later after they graduate. Therefore, universities, especially study programs must have the same paradigm. The learning process is done according to the curriculum, while the curriculum is arranged by adjusting conditions that are happening and will occur. Universities must have a concept in the development of human resources so that students have 21 st-century competence. Here are the aspects that must be mastered by students to be ready to compete in the current era.

Table 2. Competency Aspects of the Current Era

\begin{tabular}{ccc}
\hline LeatTarning Skills & Life Skills & Literacy Skills \\
\hline Problem-solving & Initiative & Technology \\
\hline Critical thinking & Leadership & Information \\
\hline Creativity & Productivity & Media \\
\hline Collaboration & Flexibility & \\
Innovation & Communication & \\
\hline
\end{tabular}

Universities must produce students who are ready to adjust the world development and the needs of the world of work which is currently being intensified in the fields of 4.0 industry and 5.0 society. Some things that are prepared in carrying out music learning in the concept of the freedom 
learning-an independent campus include the quality of education that balances between hard skills and soft skills, the relationship and relevance between what is learned and what will be the demands of the field of work, self-reliance learning for students to develop the potential skills, collaborative, supportive, and cooperative paradigms, as well as 21 st-century skills that focus on critical thinking skills, communication skills, creativity, and innovation. This is in line with the statement that Critical thinking skills are important in the context of 21st-century learning (Rosidin et al., 2019).

\section{Music Learning in New Curriculum of the Freedom Learning- An Independent Campus Policy}

In the new curriculum, four new methods can be used in applying the concept of the freedom learning in music learning for students about new policies, including giving courses in different study programs in Jakarta State University, giving courses in the same study program but outside the Jakarta State University, giving courses in different study programs outside Jakarta State University, and provide courses in the informal sector.

Table 3. New Curriculum in Application Methods of Concept the Freedom Learning-an Independent Campus

\begin{tabular}{cccl}
\hline No & \multicolumn{1}{c}{ Study Programs } & Cross & $\begin{array}{c}\text { The Freedom Learning Concept outside } \\
\text { the Study Program }\end{array}$ \\
\hline $\mathbf{1}$ & Music Education Program of UNJ & X & X Study Program (Not Music) of UNJ \\
$\mathbf{2}$ & Music Education Program of UNJ & X & Music Education Program Outside UNJ \\
$\mathbf{3}$ & Music Education Program of UNJ & $\mathrm{X}$ & X Study Program (Not Music) Outside UNJ \\
$\mathbf{4}$ & Music Education Program of UNJ & $\mathrm{X}$ & $\begin{array}{l}\text { Internship programs (industry, management, } \\
\end{array}$ \\
& & & tourism, etc.) \\
\hline
\end{tabular}

This method can only be done by the agreement among the concerned parties. Without a relationship, cooperation, and understanding, the method will not work well. The preparation that needs to be done is establishing courses that can be integrated into the bureaucratic system between units. The study program also determines courses that will be offered to students from other study programs to create a similar collaboration between the parties concerned. With the new policy related to the concept of the freedom learning-an independent campus, the education system in Indonesia will certainly develop for the better. The long-winded bureaucracy that complicates conditions needs to be trimmed down so that education in Indonesia is ready to face the rapid world-changing. The music education program of Jakarta State University fully supports new policies which are prepared to produce competent graduates who are ready to compete in the current era of the digital technology industry. 


\section{CONCLUSION AND FURTHER RESEARCH}

The challenge in implementing the new policy in the new curriculum is the collaboration mechanism among universities and study programs both inside and outside the campus. Differences in the paradigm are also a limiting factor in implementing new policies. Therefore, a mature strategy is needed to carry out the idea. Planning is an important aspect in determining the success of a program. Planning is carried out so that policies related to the application of music learning can be effective, productive, and efficient about the concept of freedom learning- an independent campus. The research results reveal that the new curriculum policy can be applied. At the research level, it explains that the music education study program is still in the planning stage of implementing new policies. So that further research is very necessary to analyze and evaluate the application of the new curriculum in the music education study program that has been carried out.

\section{REFERENCES}

Alif, S., Reka, I., \& Salsabila, N. (2020). Pro Kontra 'Kampus Merdeka' di Kalangan Mahasiswa UI [Intitution]. suaramahasiswa.com. http://suaramahasiswa.com/pro-kontra-kampus-merdekadi-kalangan-mahasiswa-ui/.

Arifin, Syamsul \& Muslim, Moh. (2020). Tantangan Implementasi Kebijakan "Merdeka

Belajar - Kampus Merdeka" pada Perguruan Tinggi Islam Swasta di Indonesia. E-ISSN : 2620-8628, P-ISSN : 2620-861X. Al-Ilmi; Jurnal Pendidikan Islam. Vol 3, No 1 (2020): MEI. DOI : 10.32529/al-ilmi.v3i1.589.

Bantwini, Bongani D. (2010). How teachers perceive the new curriculum reform: Lessons

from a school district in the Eastern Cape Province, South Africa. International Journal of Educational Development. Vol. 30, Issue 1, January 2010, Pages 83-90. https://doi.org/10.1016/j.ijedudev.2009.06.002.

Elihami, E. (2019). Implementasi Layanan Bimbingan Kelompok Dalam Meningkatkan

Higher of Think Mahasiswa Berbasis Kampus Merdeka. EduPsyCouns: Journal of Education, Psychology and Counseling, 1(1), 79-86. Retrieved from https://ummaspul.ejournal.id/Edupsycouns/article/view/324.

Fatimatur, E.R., Purwati E, \& Prabowo, A. (2020). How to Use Digital Literacy as A Learning

Resource for Teacher Candidates in Indonesia. Cakrawala Pendidikan. Vol. 39, No. 2, June 2020. DOI:10.21831/cp. v39i2.30551.

Miles, Matthew B. \& A. Michael Huberman. (2009). Analisis Data Kualitatif. Jakarta: UI-Press.

Mumpuniarti, M., Handoyo, R. R., Pinrupitanza, D. T., \& Barotuttaqiyah, D. (2020). Teacher's pedagogy competence and challenges in implementing inclusive learning in the slow learner. Cakrawala Pendidikan. https://doi.org/10.21831/cp.v39i1.28807.

Mustaghfiroh, S. (2020). Konsep “Merdeka Belajar" Perspektif Aliran Progresivisme John

Dewey. Jurnal Studi Guru Dan Pembelajaran, 3(1), 141-147. https://doi.org/10.30605/jsgp.3.1.2020.248.

Priatmoko, Sigit \& Dzakiyyah, Nilna. (2020). Relevansi Kampus Merdeka Terhadap

Kompetensi Guru Era 4.0 Dalam Perspektif Experiential Learning Theory. At-Thullab: Jurnal Pendidikan Guru Madrasah Ibtidaiyah. Volume 4 Nomor 1 Tahun 2020. P-ISSN: 2579-625 e-ISSN: 2621-895X.

Rosidin, U., Kadaritna, N., \& Hasnunidah, N. (2019). Can argument-driven inquiry models have impact on critical thinking skills for students with differentpersonality types? Cakrawala Pendidikan. https://doi.org/10.21831/cp.v38i3.24725. 
Saputra, D. N. (2020). Effort to Improve Elementary Students Interest On Music Subject With "Learning By Doing" Method Class. ADI Journal on Recent Innovation (AJRI). https://doi.org/10.34306/ajri.v2i2.74.

Sudaryanto, S., Widayati, W., \& Amalia, R. (2020). Konsep Merdeka Belajar-Kampus Merdeka dan Aplikasinya dalam Pendidikan Bahasa (dan Sastra) Indonesia. Kode: Jurnal Bahasa. https://doi.org/10.24114/kjb.v9i2.18379.

Tan, S. Y., Al-Jumeily, D., Mustafina, J., Hussain, A., Broderick, A., \& Forsyth, H. (2018).

Rethinking Our Education to Face the New Industry Era. Proceedings of EDULEARN18 Conference 2nd-4th July 2018, Palma, Mallorca, Spain, 6562-6571.

Yamin, Muhammad, Syahrir. (2020). Pembangunan Pendidikan Merdeka Belajar (Telaah

Metode Pembelajaran). Jurnal Ilmiah Mandala Education. Vol. 6. No. 1. April 2020 p-ISSN: 24429511 e-ISSN: $2656-5862$ 